\title{
PENGGUNAAN MODEL PEMBELAJARAN MAKE A MATCH SEBAGAI UPAYA MENINGKATKAN PRESTASI BELAJAR AGAMA HINDU
}

\author{
Wayan Sukarja \\ SD Negeri 3 Sukawati \\ e-mail:sukarja12@gmail.com
}

\begin{abstract}
Abstrak
Penelitian ini dilaksanakan di SD Negeri 3 Sukawati di Kelas IV B yang kemampuan siswanya untuk pelajaran Agama Hindu cukup rendah. Tujuan penulisan penelitian tindakan kelas IV B ini adalah untuk mengetahui apakah model pembelajaran Make $A$ Match dapat meningkatkan prestasi belajar siswa. Metode pengumpulan datanya adalah tes prestasi belajar. Metode analisis datanya adalah deskriptif baik untuk data kualitatif maupun untuk data kuantitatif. Hasil yang diperoleh dari penelitian ini adalah model pembelajaran Make A Match dapat meningkatkan prestasi belajar siswa. Ini terbukti dari hasil yang diperoleh pada awalnya mencapai nilai rata-rata 67,72, pada siklus I mencapai nilai rata-rata 73,4 dan pada siklus II mencapai nilai rata-rata 77,95 . Kesimpulan yang diperoleh dari penelitian ini adalah model pembelajaran Make $A$ Match dapat meningkatkan prestasi belajar Agama Hindu siswa kelas IV B SD Negeri 3 Sukawati.
\end{abstract}

Kata-kata kunci : Model pembelajaran Make A Match, Prestasi Belajar Agama Hindu

\begin{abstract}
This research was conducted at SD Negeri 3 Sukawati in Class IV B where the ability of students to study Hinduism was quite low. The purpose of writing action research class IV $\mathrm{B}$ is to find out whether the Make $A$ Match learning model can improve student achievement. The data collection method is a learning achievement test. The data analysis method is descriptive both for qualitative data and for quantitative data. The results obtained from this study are the Make A Match learning model can improve student learning achievement. This is evident from the results obtained initially reaching an average value of 67.72 , in the first cycle reaching an average value of 73.4 and in the second cycle achieving an average value of 77.95. The conclusion obtained from this study is the Make A Match learning model can improve the learning achievement of Hindu Religion grade IV B students at SD Negeri 3 Sukawati.
\end{abstract}

Keywords: Make A Match learning model, Hindu Learning Achievement 


\section{Pendahuluan}

Penerapan sistem pendidikan modern di Indonesia sejak pertengahan abad ke-19 mengakibatkan pe-ngaruh kebudayaan modern yang bercorak intelek-tualistis, materialistis, dan individualis semakin meluas di Bali (Geriya, 2000: 3; Atmaja, 2001: 17). Pengaruhnya terhadap kebudayaan Bali me-nonjol sejak awal abad ke-20 (Mantra, 1996:1), akibatnya keajegan kebudayaan Bali tradisional yang berkarakterkan budaya ekspresif yang berciri-kan nilai-nilai religius, estetika, dan solidaritas berada pada posisi dilematis. Dinamikanya menun-jukkan dua arah perkembangan, di satu sisi ber-proses ke arah integrasi adaptif dan di sisi lain juga menunjukkan dialektik antagonistik (Geriya, 2000:3). Dinamika yang mengarah ke integrasi adaptif disebabkan oleh adanya gejala bahwa orang (Bali) tidak mau kehilangan kepribadiannya (Mantra, 1996: 6). Kebudayaan Bali telah memperlihatkan daya tahan dari abad ke abad menghadapi perubahan-perubahan karena sifatnya yang luwes, dinamis, adoptif, adaptif, dan kreatif. Mantra (1996: 14) menyatakan keyakinanya: "Sepanjang kedudukan dan fungsi seni budaya masih kuat dalam kehidupan keluarga dan masyarakat Bali, dan upacara-upacara dari kelahiran sampai mati masih kokoh, maka seni budaya akan selalu hidup dan merakyat". Di sisi lain pengaruh modernisasi juga mengakibatkan berbagai benturan budaya tidak dapat dihindari. Ini muncul dalam berbagai kasus yang membawa dampak negatif: fenomena distorsi, degradasi, demoralisasi sampai dengan berbagai pelecehan kultural (Geriya, 2000: 3). Naya Sujana (dalam Geriya, 2000: 5) berkesim-pulan bahwa dinamika kebudayaan Bali tradisional menuju kebudayaan Bali modern mengandung ancaman serius, krisis, dan semakin tidak berdaya. Kebudayaan Bali tengah mengalami distorsi, diskontinu, dan disintegrasi. Dari sisi sosial dan pendidikan, Bawa Atmadja (2001: 22-30) menya-takan bahwa masyarakat Bali mengalami disorga-nisasi sosial yang teraktualisasi dalam perilaku menyimpang yang dapat dipilah menjadi tiga: kesukaran semantik, konversi agama, dan menguat-nya budaya konsumen. Dalam bidang agama, kehadiran penganut aliran agama Hindu "baru" tumbuh menjadi umat yang bersifat progresif dengan ideology dalam tampilan sekterian beratribut ekspresif budaya India. Akibatnya, bermunculanlah konflik sosial-religius di sejumlah desa pakraman di Bali. Hal itu dipicu pula oleh sikap dan perilaku antipati dari sejumlah tokoh Hindu tradisional, bahwa kehadiran mereka itu tidak selaras dengan rasa tradisi Bali dan karena itu berbahaya bagi keajegan budaya dan agama Hindu Bali. Oleh sebab itu, tokoh-tokoh agama Hindu Bali tradisional melakukan berbagai usaha (Paramartha, 2017).

Di Surabaya, suku bangsa yang berasal dari berbagai wilayah di Indonesia hidup berdampingan di tengah segala perbedaan pola pemikiran, sistem nilai, norma, kebiasaan, adat, dan sejarah antara satu dengan yang lain. Dari berbagai suku bangsa yang ada di Surabaya, salah satu yang melakukan upaya pelestarian eksistensi kebudayaannya adalah suku bangsa Bali. Mayoritas umat Hindu di Surabaya merupakan orang Bali, komunitas ini memiliki ikatan kekerabatan yang kuat berdasarkan sistem banjar (Sistem banjar merupakan sebuah bentuk himpunan masyarakat yang berdasarkan satu kesatuan lingkungan, unsur pengikat bagi warga anggotanya adalah batas wilayah teritorial tersebut sesuai dengan peraturan banjar yang berlaku (awig-awig). Di Bali, keberadaan banjar merupakan bagian terkecil dari administratif desa adat atau desa pekraman. Keanggotaannya bersifat terbuka, di mana anggota banjar bukan hanya mereka yang lahir di desa tersebut, tetapi warga dari luar desa juga diperbolehkan bergabung menjadi warga anggota banjar (http://erabaru.net>erabarunews $>$ wisata, diakses pada 23 Desember 2012). Komunitas Hindu-Bali tersebut tergabung dalam Banjar Surabaya ( Banjar Surabaya adalah suatu organisasi sosial kemasyarakatan umat Hindu di dalam satu lingkup batas wilayah, yaitu wilayah Surabaya yang mengikat anggotanya berdasarkan persamaan adat dan tradisi kebudayaan yang bertujuan untuk meningkatkan kebersamaan umat dalam menjalankan segala kegiatan keagamaan sesuai dengan ajaran dharma dalam suka maupun duka. Banjar Surabaya diketuai oleh seorang ketua banjar dan terbagi ke dalam 22 sektor wilayah berdasarkan wilayah kecamatan di Surabaya yang masing-masing wilayah diketuai oleh ketua sektor banjar (Keputusan Ketua Banjar No. 33/ X/ SK/ BS/2011) (Wihantari, 2013).

Pendidikan sangat penting bagi kehidupan umat manusia. Pendidikan merupakan upaya yang sangat luhurdalam meningkatkan kualitas manusia, sehingga segala usaha yang mengarah pada keberhasilan pendidikan merupakan sebuah keharusan. Sebagaimana tercantum dalam UndangUndang Republik Indonesia Nomor 20 tahun 2003 tentang sistem pendidikan nasional, pendidikan adalah usaha sadar dan terencana untuk mewujudkan suasana belajar dan proses pembelajaran agar peserta didik secara aktif mengembangkan potensi dirinya untuk memiliki kekuatan spiritual keagamaan, pengendalian diri, kepribadian, kecerdasan, Aqidah Akhlak, serta keterampilan yang diperlukan dirinya, masyarakat, bangsa dan negara (UUSPN, No, 20, $2003: 3$ ). Keberhasilan dalam bidang pendidikan melalui proses pembelajaran di sekolah sangat dipengaruhi oleh beberapa faktor diantaranya yaitu peserta didik, kurikulum, tenaga pendidik, biaya, sarana dan prasarana serta faktor lingkungan. Apabila 
faktor-faktor tersebut dapat terpenuhi, sudah tentu akan memperlancar proses pembelajaran. Keberhasilan dalam bidang pendidikan akan meningkatkan kualitas pendidikan. Untuk meningkatkan kualitas pendidikan, maka perlu adanya proses pembelajaran yang bermutu dan berkualitas. Baik bermutu pada prosesnya maupun prestasi akhir pembelajaran yaitu prestasi belajar. Prestasi belajar merupakan tolok ukur yang utama untuk mengetahui keberprestasian belajar siswa. Siswa yang prestasinya tinggi dapat dikatakan bahwa ia telah berprestasi dalam pembelajaran, dan sebaliknya siswa yang prestasi belajarnya rendah dapat dikatakan belum berprestasi dalam pembelajaran. Belajar adalah suatu proses yamg ditandai dengan adanya perubahan pada diri seseorang. Perubahan dalam diri seseorang dapat ditunjukkan dalam berbagai bentuk seperti berubahnya pengetahuannya, pemahamannya, sikap dan tingkah lakunya, keterampilan dan kemampuannya, daya reaksinya, daya penerimaannya dan lain-lain aspek yang ada pada individu (Sudjana,2002 :280) (Susanty, 2014).

Pendidikan dan pengajaran adalah salah satu usaha yang bersifat sadar tujuan yang dengan sistematis terarah pada perubahan tingkah laku menuju kedewasaan anak didik. Perubahanperubahan itu menunjukkan suatu proses yang harus dilalui. Perubahan tidak hanya berkaitan dengan penambahan ilmu pengetahuan, tetapi juga berbentuk kecakapan, keterampilan, sikap, pengertian, harga diri, minat, watak, dan penyesuaian diri (Sardiman, 2009). Menurut Djamarah dan Zain (2010) bahwa proses belajar mengajar adalah suatu proses yang sengaja diciptakan untuk kepentingan anak didik. Agar anak didik senang dan bergairah belajar, guru berusaha menyediakan lingkungan belajar yang kondusif dengan memanfaatkan semua potensi kelas yang ada. Di dalam kegiatan belajar mengajar guru tidak harus terpaku dengan menggunakan satu metode, tetapi guru sebaiknya menggunakan metode yang bervariasi agar jalannya pembelajaran tidak membosankan tetapi menarik perhatian anak didik. Pada intinya belajar adalah ingin mendapatkan pengetahuan, keterampilan, dan pemahaman sikap mental, serta nilai-nilai (Sardiman, 2009). Dalam proses pembelajaran, guru sebagai fasilitator atau motivator memegang peranan penting dalam proses belajar mengajar. Guru harus bisa menciptakan kondisi yang dinamis dan mampu meningkatkan kualitas pembelajaran, untuk itu guru harus memilih salah satu model-model pembelajaran yang bisa meningkatkan semangat siswa untuk belajar agar siswa tidak merasa bosan berada didalam kelas. Dalam kelas metode mengajar tidak digunakan sendiri-sendiri tetapi merupakan kombinasi dari beberapa metode mengajar (Sudjana,2012).( Wandy, 2017).

Mata pelajaran Agama Hindu perlu diberikan kepada semua peserta didik mulai dari sekolah dasar untuk membekali peserta didik dengan kemampuan berpikir logis, analitis, sistematis, kritis, dan kreatif, serta kemampuan bekerjasama. Kompetensi tersebut diperlukan agar peserta didik dapat memiliki kemampuan memperoleh, mengelola, dan memanfaatkan informasi untuk bertahan hidup pada keadaan yang selalu berubah, tidak pasti, dan kompetitif.

Pendekatan pemecahan masalah merupakan fokus dalam pembelajaran Agama Hindu yang mencakup masalah tertutup dengan solusi tunggal, masalah terbuka dengan solusi tidak tunggal, dan masalah dengan berbagai cara penyelesaian. Untuk meningkatkan kemampuan memecahkan masalah perlu dikembangkan keterampilan memahami masalah, membuat model Agama Hindu, menyelesaikan masalah, dan menafsirkan solusinya.

Dalam setiap kesempatan, pembelajaran Agama Hindu hendaknya dimulai dengan pengenalan masalah yang sesuai dengan situasi (contextual problem). Dengan mengajukan masalah kontekstual, peserta didik secara bertahap dibimbing untuk menguasai konsep Agama Hindu. Untuk meningkatkan keefektifan pembelajaran, sekolah diharapkan menggunakan teknologi informasi dan komunikasi seperti komputer, alat peraga, atau media lainnya (Depdiknas, 2006).

Mata pelajaran Agama Hindu bertujuan agar peserta didik memiliki kemampuan sebagai berikut: 1) Memahami konsep Agama Hindu, menjelaskan keterkaitan antar konsep dan mengaplikasikan konsep atau algoritma, secara luwes, akurat, efisien, dan tepat, dalam pemecahan masalah. 2) Menggunakan penalaran pada pola dan sifat, melakukan manipulasi Agama Hindu dalam membuat generalisasi, menyusun bukti, atau menjelaskan gagasan dan pernyataan Agama Hindu. 3) Memecahkan masalah yang meliputi kemampuan memahami masalah, merancang model Agama Hindu, menyelesaikan model dan menafsirkan solusi yang diperoleh. 4) Mengomunikasikan gagasan dengan simbol, tabel, diagram, atau media lain untuk memperjelas keadaan atau masalah. 5) Memiliki sikap menghargai kegunaan Agama Hindu dalam kehidupan, yaitu memiliki rasa ingin tahu, perhatian, dan minat dalam mempelajari Agama Hindu, serta sikap ulet dan percaya diri dalam pemecahan masalah.

Pemberlakuan pelajaran Agama Hindu diarahkan untuk proses meningkatkan pemahaman dan kemampuan siswa menganalisis sehingga dapat membantu siswa untuk memperoleh pemahaman yang lebih mendalam. Proses pembelajaran Agama Hindu yang terjadi selama ini sering terjadi permasalahan. Permasalahan yang sering timbul selama ini di lapangan adalah cara mengajar guru yang sering menggunakan metode konvensional dan menjelaskan materi sesuai dengan yang ada di buku paket 
maupun LKS. Selain itu, dalam proses pembelajaran guru belum menggunakan model pembelajaran yang mendukung dalam penjelasan materi.

Kondisi yang sama juga terjadi di SD Negeri 3 Sukawati Berdasarkan hasil observasi yang peneliti lakukan, dapat diketahui bahwa pembelajaran Agama Hindu di kelas IV B masih dilakukan secara konvensional. Metode yang digunakan masih dengan metode ceramah, yaitu siswa hanya mendengarkan pada saat guru sedang menjelaskan, proses pembelajaran hanya berpusat pada guru. Akibatnya prestasi belajar siswa hanya mencapai nilai rata-rata 67,72.

Menghadapi kondisi yang sangat mengkhawatirkan, maka perlu adanya upaya perbaikan dalam proses pembelajaran agar dapat meningkatkan keterampilan proses dalam pembelajaran Agama Hindu yaitu khususnya pada kemampuan analisis dalam memahami materi Agama Hindu. Salah satu alternatif yang digunakan yaitu dengan menggunakan model pembelajaran Make A Match.

Model Pembelajaran Make A Match (membuat pasangan) merupakan salah satu jenis dari metode dalam pembelajaran kooperatif. Model pembelajaran make and match adalah sistem pembelajaran yang mengutamakan penanaman kemampuan sosial terutama kemampuan bekerjasama, kemampuan berinteraksi disamping kemampuan berpikir cepat melalui permainan mencari pasangan dengan dibantu kartu (Wahab, 2007 : 59).

Dengan model pembelajaran Make $A$ Match tersebut merupakan suatu cara mengajar untuk menanamkan kebiasaan-kebiasaan tertentu dimana anak melaksanakan kegiatan-kegiatan latihan secara berulang-ulang, agar anak memiliki ketangkasan atau keterampilan yang lebih tinggi dari apa yang dipelajari sebelumnya. Semakin sering pengulangan dilakukan akan semakin tinggi tingkat keterampilan peserta didik menguasai materi yang diajarkan. Dengan cara tersebut menurut peneliti merupakan suatu cara yang dapat memberikan percepatan dalam proses pencapaian tujuan pembelajaran karena dapat menciptakan suasana belajar yang kondusif dan menyenangkan bagi anak. Dengan menggunakan cara ini tanpa disadari anak bahwa dalam proses bermainnya ada pembelajaran yang sedang dijalani dengan berulang.

Berdasarkan pemaparan di atas, penelitian ini akan mengambil judul tentang Penggunaan Model Pembelajaran Make A Match Sebagai Upaya Meningkatkan Prestasi Belajar Agama Hindu Siswa Kelas IV B SD Negeri 3 Sukawati Semester I Tahun Pelajaran 2018/2019.

\section{Metode}

Tempat Pada penelitian ini, peneliti memilih rancangan yang sesuai dengan penelitian yang dilakukan yaitu penelitian tindakan kelas (PTK). Penelitian tindakan kelas ini dilakukan agar dapat memecahkan suatu masalah yang dialami oleh seorang guru ketika mengajar di kelas. Penelitian ini nantinya akan terdiri dari dua siklus untuk melakukan perbaikan proses dan hasil pembelajaran. Perbaikan kualitas proses dan hasil pembelajaran dalam penelitian ini dilakukan pada mata pelajaran Agama Hindu. Menurut Agung (2014: 139) "Tiap siklus terdiri atas empat tahapan yaitu: perencanaan, pelaksanaan tindakan, observasi/evaluasi dan refleksi".

1. Perencanaan

Perencanaan tindakan meliputi: 1) Menyusun rencana pelaksanaan pembelajaran sesuai standar kompetensi, kompetensi dasar dan indikator yang telah ditetapkan.

2. Pelaksanaan Tindakan

Pelaksanaan tindakan dilakukan sesuai prosedur yang telah dirancang.

3. Observasi/Evaluasi

Dalam kegiatan ini yang diobservasi adalah: a) Mengobservasi proses pembelajaran, dan 2) Memberi penilaian terhadap siswa.

4. Refleksi

Refleksi dilakukan untuk merenungkan dan mengkaji hasil tindakan pada siklus I.

Dalam penelitian tindakan kelas (PTK) ini mengacu pada teori yang dikemukakan Kemmis dan Taggrat (dalam Agung, 2014: 140). Model penelitian ini terdapat empat tahapan pada satu siklus penelitian empat tahapan tersebut sesuai dengan yang telah dijelaskan di atas. Siklus ini dapat digambarkan sebagai berikut. 


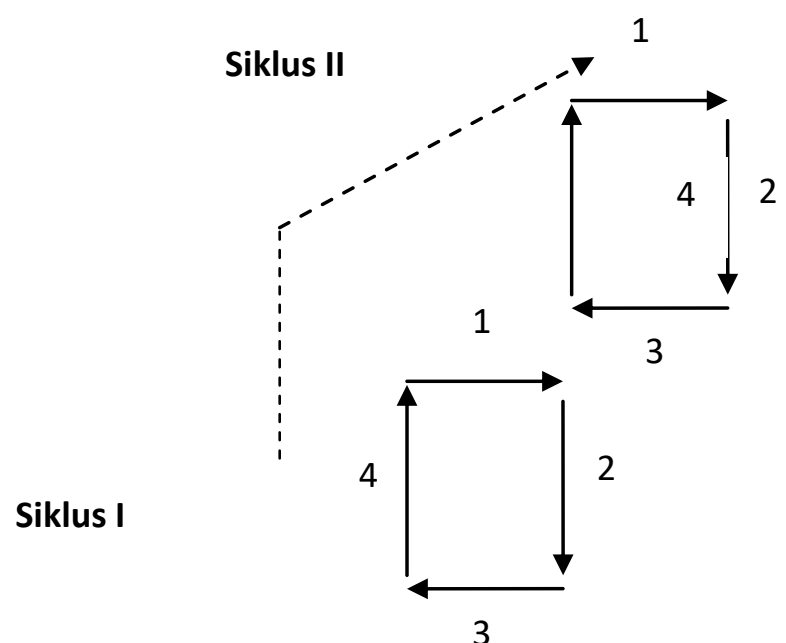

Gambar 1. Model PTK Dua Siklus (Agung, 2014: 141)

\section{Keterangan:}

1. Tahap perencanaan

2. Tahap tindakan

3. Tahap observasi/evaluasi

4. Tahap refleksi

5.

Indikator keberhasilan penelitian yang diusulkan dalam penelitian ini pada siklus I dan II mencapai nilai rata-rata 75,00 dengan ketuntasan belajar $85 \%$. dengan KKM yang ditetapkan untuk mata pelarajan Agama Hindu pada SD Negeri 3 Sukawati adalah 75.

\section{Hasil dan Pembahasan}

Model pembelajaran mengacu pada pendekatan yang akan digunakan, termasuk di dalamnya tujuan-tujuan pembelajaran, lingkungan pembelajaran, dan pengelolaan kelas, mengemukakan maksud dari model pembelajaran adalah: Kerangka konseptual yang melukiskan prosedur yang sistematis dalam mengorganisasikan pengalaman belajar untuk mencapai tujuan belajar tertentu, dan berfungsi sebagai pedoman bagi para perancang pembelajaran dan para pengajar dalam merencanakan aktivitas belajar mengajar. Model pembelajaran merupakan suatu pola yang dipakai oleh guru untuk membentuk kurikulum, artinya para guru boleh memilih model pembelajaran yang sesuai dan efisien untuk mencapai tujuan pembelajarannya.

Model pembelajaran yang cocok diterapkan di sekolah dasar adalah model pembelajaran Make A Match. Menurut Tarmizi dalam Novia (2015: 12 ) menyatakan bahwa model pembelajaran Make $A$ Match artinya siswa mencari pasangan setiap siswa mendapat sebuah kartu (bisa soal atau jawaban) lalu secepatnya mencari pasangan yang sesuai dengan kartu yang ia pegang.

Adapun langkah-langkah pelaksanaan model pembelajaran Make $A$ Match menurut Aqib zainal (2013 : 23 ) adalah sebagai berikut: 1) Guru menyiapkan beberapa kartu yang berisi beberapa konsep atau topik yang cocok untuk sesi review (satu sisi berupa kartu soal dan sisi sebaliknya berupa kartu jawaban), 2) Setiap siswa mendapat satu kartu dan memikirkan jawaban atau soal dari kartu yang dipegang, 3) Siswa mencari pasangan yang mempunyai kartu yang cocok dengan kartunya (kartu soal atau kartu jawaban), 4) Siswa yang dapat mencocokan kartu nya sebelum batas waktu diberi poin, 5) Setelah satu babak kartu dikocok lagi agar tiap siswa mendapat kartu yang berbeda dari sebelumnya, demikian seterusnya, dan 6) Kesimpulan.

Berdasarkan penelitian yang telah dilakukan dengan menerapkan model pelajaran Make $A$ Match didapatkan hasil bahwa: pada siklus I memperoleh hasil yang lebih baik dari proses awal, yaitu dengan rata-rata nilai 73,4 dari jumlah nilai secara klasikal 1615 seluruh siswa SD Negeri 3 Sukawati, dan prosentase ketuntasan belajarnya adalah $72,72 \%$, yang tidak tuntas adalah $27,27 \%$. Hasil ini belum maksimal, karena belum mecapai indikator keberhasilan penelitian yang mencanangkan dengan minimal prosentase ketuntasan belajar $85 \%$.

Dengan tindakan yang sangat maksimal dan pelaksanaan yang betul-betul mengikuti kebenaran teori sesuai dengan model pembelajaran Make A Match dalam pembelajaran Agama Hindu SD Negeri 3 Sukawati, dimana hasil yang diperoleh pada siklus II ini ternyata Hasil belajar Agama Hindu meningkat 
secara signifikan dengan nilai rata-rata 77,95 dan ketuntasan belajarnya adalah $100 \%$. Dari keseluruhan jumlah siswa yaitu 22 orang siswa 22 orang siswa telah mampu melampaui nilai KKM yaitu 75.

Adapun kelebihan model Make A Match pada penelitian ini adalah: 1) Mampu menciptakan suasana aktif dan menyenangkan, 2) Materi pembelajaran yang disampaikan lebih menarik perhatian siswa, 3) Mampu meningkatkan hasil belajar siswa mencapai taraf ketuntasan belajar, 4) Suasana kegembiraan akan tumbuh dalam proses pembelajaran, 5) Kerja sama antar siswa terwujud dengan dinamis, dan 6) Munculnya dinamika gotong royong yang merata diseluruh siswa.

Hasil penelitian ini sejalan dengan hasil penelitian yang dilakukan oleh Fitriani, dkk (2016) yang berjudul Penerapan Model Pembelajaran Kooperatif Tipe Make A Match Untuk Meningkatkan Motivasi, Aktivitas, Dan Hasil Belajar Biologi Kelas X.1 SMAN 1 Dua Boccoe Kabupaten Bone. Hasil penelitian menunjukkan bahwa: (1) Terjadi peningkatan motivasi belajar dengan nilai rata-rata pada siklus I 76,3 menjadi 77,7 (2) Ada peningkatan aktivitas belajar, nilai rata-rata persentase aktivitas pada siklus I sebesar $86 \%$ menjadi $95 \%$ pada siklus II. (3) Terjadi Peningkatan hasil belajar pada siklus I dengan persentase ketuntasan $53 \%$ dan pada siklus II meningkat menjadi $88 \%$. Model pembelajaran kooperatif tipe Make A Match dapat meningkatkan motivasi, aktivitas, dan hasil belajar kognitif biologi siswa.

Penelitian yang dilakukan oleh Riyanti (2018) yang berjudul Penerapan Model Pembelajaran Kooperatif Tipe Make A Matchuntuk Meningkatkan Hasil Belajar IPS. Penelitian ini menggunakan Penelitian Tindakan Kelas.(PTK).Teknik pengumpulan data yang digunakan adalah observasi, tes dan catatan lapangan. Pelaksanaan pembelajaran mengalami peningkatan pada siklus I $72,2 \%$ dan pada siklus II meningkat menjadi $88,8 \%$. Hasil belajar siswa juga mengalami peningkatan dari siklus I $62,5 \%$ dan pada siklus II meningkat menjadi $93,75 \%$. Dari hasil tersebut, dapat disimpulkan bahwa penerapan model pembelajaran kooperatif tipe Make $A$ Match dapat meningkatkan hasil belajar siswa pada mata pelajaran IPS.

\section{Simpulan dan Saran}

Berdasarkan pemaparan di atas, dapat disimpulkan bahwa Model Pembelajaran Make A Match Sangat Efektif Digunakan Untuk Meningkatkan Prestasi Belajar Agama Hindu Siswa Kelas IV B SD Negeri 3 Sukawati Semester I Tahun Pelajaran 2018/2019.

Saran yang dapat disampaikan pada penelitian ini adalah sebagai berikut; 1) Siswa disarankan untuk fokus dan aktif dalam belajar, terutama dalam kegiatan diskusi baik dengan teman maupun guru. 2) Guru disarankan untuk menggunakan inovasi-inovasi pembelajaran, sehingga siswa tidak merasa jenuh dalam belajar. 3) Sekolah disarankan untuk menyediakan sarana dan prasarana yang menunjang kegiatan pembelajaran di kelas. 4) Peneliti lain disarankan untuk mengembangkan penelitian ini sehingga permasalahan-permasalahan yang terjadi di dunia pendidikan dapat diatasi secara optimal.

\section{Daftar Pustaka}

Agung, A. A. Gede. 2014. Metodologi Penelitian Pendidikan. Singaraja: Undiksha.

Amri, Sofan. 2013. Peningkatan Mutu Pendidikan SD dan Menengah. Jakarta: PT. Prestasi Pustakaraya.

Aqib, Zainal. 2013. Model-model, Media, dan Strategi Pembelajaran Kontekstual. (Inovatif). Bandung: Yrama Widya.

Arikunto, Suharsimi; Suhardjono; Supardi. 2006. Penelitian Tindakan Kelas. Jakarta: PT Bumi Aksara.

Daryanto. 1999. Evaluasi Pendidikan. Rineka Cipta: Jakarta.

Depdiknas, 2003c.Sistem Penilaian Kelas SD, SD, SMA dan SMK. Dirjen Dikdasmen Tendik.

Depdiknas. 2006. Kurikulum Tingkat Satuan Pendidikan. Jakarta : Depdiknas.

Depdiknas. 2011. Membimbing Guru dalam Penelitian Tindakan Kelas. Jakarta: Pusat Pengembangan Tenaga Kependidikan Badan Pengembangan Sumber Daya Manusia Pendidikan dan Menjaminan Mutu Pendidikan.

Susanty, Ella. 2014. Pengaruh Pembelajaran Cooperatif Tipe Make A Match Dan Pembelajaran Konvensional Terhadap Hasil Belajar Pkn Ditinjau Dari Kemandirian Belajar Siswa Pada Mts N 
Di Kabupaten Kudus . Jurnal Teknologi Pendidikan Dan Pembelajaran Vol.2, No.2, Hal 257 272, Edisi April 2014

Paramartha, Wayan. 2017. Mengungkap Model Pendidikan Hindu Bali Tradisional Aguron-guron . Jurnal Seni Budaya Volume 32, Nomor 1, Februari 2017

Wahab, Abdul Aziz. 2007. Metode dan Model-Model Mengajar. Bandung: Alfabeta.

Wandy. 2017. Metode Pembelajaran Make A Match Untuk Meningkatkan Hasil Belajar Bahasa Indonesia Siswa Sekolah Menengah Pertama . Jurnal Ilmu Pendidikan Sosial, sains, dan Humaniora Vol. 3 No. 1, Maret 2017.

Wihantari, Biyas. 2013. Studi Etnografi Penanaman Nilai Agama Hindu Pada Anak Oleh Anggota Banjar Surabaya. Jurnal Antropologi FISIP-UNAIR Vol.2.No.1.Jan.-Pebruari 2013 